\title{
Herbert Spencer, Gerard Hopkins, and the Force of Poetic Expression
}

\author{
MICHAEL MEEUWIS \\ University of Warwick
}

Let's begin with a bare fact about Victorian poetry: it enjoyed a social influence that poetry now does not. ${ }^{1}$ It follows that social theorists might have been interested in poetry. In fact, one of the most prominent Victorian social theorists, Herbert Spencer, addresses poetry in a largely unread section of his 1854 essay "The Philosophy of Language."2 Spencer's article has most often been taken as a simple endorsement of brevity in language: that shorter words and simpler sentences facilitate communication. Yet Spencer's true interest is in how language can create effects on bodies. These are not always best served by brevity but instead by the density of meaning exemplified by poetic language. In this essay, I show how Spencer's theory about how poetic language can achieve public effect can help us to understand a critically neglected concern with public influence in the poetry of Gerard Manley Hopkins.

Spencer and Hopkins provide intricate and complementary accounts of one specific phenomenon: poetic language's ability to motivate behavior within a wide population. Spencer's concept of “excitement" and Hopkins's equivalent idea of "charge" both imagine poetic language traveling through a population. Spencer's use of "excitement" is not idiosyncratic; he describes poetry as a means by which one human may motivate another through lan-

I would like to thank Chalcedony Wilding and Kasia Bartoszynska for their patient advice on drafts of this article; and my colleagues at the Bilkent University Department of Cultures, Civilizations, and Ideas for their input on this article in its earliest stages.

1. Victorian poetry, as Antony Harrison notes, was consumed "in more varied forms than was other literature," from schoolrooms to public orations to family recitations (Victorian Poets and the Politics of Culture [Charlottesville: University Press of Virginia, 1998], 11).

2. I cannot find any scholars who have commented on the poetry section of Spencer's essay. Those who have written on the essay restrict their comments to Spencer's account of concision in prose composition. So, John Guillory critiques Spencer's ideal of linguistic "compression." See "The Memo and Modernity," Critical Inquiry 31 (2004): 125.

(C) 2015 by The University of Chicago. All rights reserved. 0026-8232/2015/11302-0005\$10.00 
guage. Hopkins, by contrast, makes a slightly nonstandard use of "charge." Hopkins describes a world that is, as he famously writes, "charged with the grandeur of God." God motivates and energizes all things in the worldincluding, but not limited to, electricity. ${ }^{4}$ This "charge" may, or may not, be noticed by human observers. Yet a poem may bring it out to the reader, who will then experience its full force. Both "excitement" and "charge" describe a nonrational, unreflective emotion that builds up in the poet, causing him to produce poetic language that-whether witnessed firsthand or read in print-causes others to respond with an excitement of their own.

Claiming that printed poetic language could hold and convey "excitement" or "charge" combines elements of both oral and print cultures. Oral cultures are premised on immediate presence and tend toward the synchronic; print cultures do not require immediate presence and tend toward the diachronic. ${ }^{5}$ However, as Ivan Kreilkamp notes, "Victorian print culture" in general "grants special authority to forms of writing that pay homage to, or even pass themselves off as, transcriptions of ... voice." " Presenting one form of what Kreilkamp terms "Vocalized print," Hopkins and Spencer describe theories of poetry that claim synchronic print can reconstitute diachronic verbal presence. ${ }^{7}$ Writing, in other words, can store the energy of speech. This energy can in turn return to full immanence-will "flame out"-when read.

Hopkins and Spencer each describe what might be termed a poetry of social success: that is, a poetry that will induce certain thoughts and behavior within a mass population. Two contemporary accounts of Victorian poetry are relevant here. Yopie Prins describes how Victorian poetry in gen-

3. Gerard Manley Hopkins, "God's Grandeur," line 1, in The Poetical Works of Gerard Manley Hopkins, ed. N. H. Mackenzie (Oxford: Clarendon, 1990). All subsequent references to Hopkins's poetry are to this edition, made parenthetically by line number.

4. Electricity is, of course, an important part of Hopkins's understanding of "charge." This has been argued most persuasively by Jason Rudy, who notes, "Electricity becomes a figure in Hopkins' poetry for the work that he imagines poetic form-and stress in particular-to accomplish" (Electric Meters: Victorian Physiological Poetics [Athens: Ohio University Press, 2009], $130)$.

5. See Walter J. Ong, Orality and Literacy: The Technologizing of the Word (London: Methuen, 1982).

6. Ivan Kreilkamp, Voice and the Victorian Storyteller (Cambridge University Press, 2005), 6. Kreilkamp does not claim that this "transcription" was always successful. Instead, he surveys the "problematic of voice" in Victorian print, noting statements of belief and disbelief in writing's ability to reproduce voice. "Novel criticism," he notes, "wavers between dismay at the effacement or overwhelming of voice by writing, and pleasure at the sound of voice ringing out from print - as if the successful conjuring of speech in writing were the novel's ultimate self-realizing" (23-24). Hopkins and Spencer are clearly believers in the later category-in writing's ability to perform such a "conjuring" of speech.

7. Ibid., 21. 
eral explored a mass "mediation between the ear and the eye that produces the possibility of multiple voicings." ${ }^{8}$ While some Victorian poets opened up spaces of multiplicity for readers to fulfill in individual "enunciation," others sought to limit readerly choice through metrics that emphasized "codification," and so standardization. ${ }^{9}$ Similarly, Isobel Armstrong, discussing Hopkins in particular, notes that the poet "was torn between a primitive account of language asserting the primordial relation between word and thing ... and one which asserts the independence of the sign and the chasm of irredeemable difference between language and things in the extralinguistic world." ${ }^{\prime 10}$ In his writing on poetry, Spencer strongly limits both the reader's freedom and poetic language's polyvalent possibility. What he favors is a linguistic system that is maximally stable between writers and readers, ensuring the accurate reproduction of experiences between them. Spencer allows us to recognize the moments when Hopkins shows a similar tendency: when the poet marshals this "primordial" account of language in the interests of converting others to his beliefs. At these moments of intended conversion, language points to experiences that all humansHopkins asserts-experience in the same way.

I will first examine Spencer's claim that poetic language must influence the public. Spencer would, famously, later coin the phrase "survival of the fittest." In the earlier essay, Spencer applies a similar logic to poetry: poetry is memorable language passed on through repetition from one person to another and thereby able to thrive - to effect change-amid the conditions of everyday life. I will then show how Hopkins's poetic theory and theology describe, and his poetry itself fulfills, this requirement. Hopkins seeks a poetry of successful public intervention to promote English Catholic reconversion. His own conversion and career as a preacher and poet took place during a renewed campaign by English Catholicism to gain influence over the newly unified national culture that Mary Poovey finds in midcentury England. ${ }^{12}$ The Liberal statesman and editor Walter Bagehot was a contem-

8. Yopie Prins, "Victorian Metres," in The Cambridge Companion to Victorian Poetry, ed. Joseph Bristow (Cambridge University Press, 2000), 92.

9. Ibid, 110, 106. As Joshua King writes, many writers of what was known as the New Prosody, among them Hopkins and his late-life friend Coventry Patmore, shared the "hope ... of affirming a shared pattern in human emotional experience by discovering laws of English metre" that would create the same effects in disparate readers (Joshua King, "Patmore, Hopkins, and the Problem of the English Metrical Law," Hopkins Quarterly 38 [2011]: 45 [published in conjunction with Victorian Poetry 49, no. 2 (2011)]).

10. Isobel Armstrong, Victorian Poetry: Poetry, Poets and Politics (London: Routledge, 1996), 419.

11. Herbert Spencer, Principles of Biology (London: Williams \& Knobgate, 1864), 444.

12. Mary Poovey, Making a Social Body: British Cultural Formation, 1830-1864 (University of Chicago Press, 1995), 4. There is not room in this essay to do justice to the complex scholarship regarding English Catholicism's attempt to influence national life. I am particularly indebted 
porary observer of this unified culture. Bagehot wrote that a "sensitive talking world" - a national conversation-now connected all of the members of the population. ${ }^{13}$ In some journalistic and political theories, the Victorians imagined all members of the population as potentially in conversation with each other, moving speech, ideas, and influence across a wide population.

Spencer's concept of poetry, one such theory of influence, helps us to read two of the most basic elements of Hopkins's poetry. On the macrolevel, Hopkins maintained a career-long interest in the idea that poetry must be publicly influential. This belief manifested itself in his microlevel interest in the intricate physical processes by which poetry moves from the world to poetic inspiration to the reader's brain.

Both Spencer and Hopkins believe that writing can grab a reader's attention in the way that a shout might. In an 1882 letter to Robert Bridges, Hopkins writes that poetry must place the poet physically in control of the reader's body. ${ }^{14} \mathrm{He}$ describes "finding the ear of an audience ... a nameless quality which is of the first importance ... I sometimes call it bidding. I mean the art or virtue of saying everything right to or at the hearer, interesting him, holding him in the attitude of correspondent or addressed or at least concerned." "The poet's "art" involves holding the attention of readers by making them virtual listeners. Poetry on the page can address the "ear" of a virtual "hearer." In fact it must do so, Hopkins writes, in order to truly be considered poetry.

Hopkins's poetry can be read as an extended performance of calling out God's charge to the reader. "The Wreck of the Deutschland" (1875-76), "No Worst, there is none" (1885), and "Spelt from Sibyl's Leaves" (1885) all claim that if God's presence, which Hopkins calls "charge," is passed along to the reader, then poetry has occurred. Hopkins paid insistent attention to the quotidian mechanics of charge: the vibration of sound through air, the movement of breath through the respiratory system, the inspiring of the poet that creates the poem itself. In "The Wreck of the Deutschland," the world is a language. This language, if parsed correctly, creates in its reader

to Eric Griffiths's account of Hopkins's efforts as part of Newman's attempts to influence the national conversation. See The Printed Voice of Victorian Poetry (Oxford: Clarendon, 1989), esp. 267.

13. Walter Bagehot, quoted in Griffiths, Printed Voice, 76. I discuss Bagehot's ideas in greater depth in Michael Meeuwis, "Representative Government: The 'Problem Play,' Quotidian Culture, and the Making of Social Liberalism," ELH 80 (2013): 1093-1120.

14. Jenny Holt presents a thoughtful reading of the relationship between speaker and hearer in Hopkins considered in terms of Hegel's master-slave dialectic. She focuses in particular on Hopkins's lyric speaker's "power to exploit language, and use it arbitrarily" to control the hearer ("The Negotiation of Power Relations in Gerard Manley Hopkins' 'The Wreck of the Deutschland' and Sonnets about Working-Class Men," Victorian Poetry 38 [2000]: 300).

15. Gerard Manley Hopkins to Thomas Bridges, quoted in Griffiths, Printed Voice, 327. 
an awareness of God's charge suffusing the world. It is the role of the speaker to translate this language for the reader. This translation works if the reader becomes connected, through language, to God's charge. Awareness of God is connection to his charge. It excites us further to know that his energy moves us and all things.

The requirement that poetry influence a reader in this way also serves as a source of anguish in Hopkins's late meditations on poetic failure and religious absence. These late sonnets use public influence to diagnose their own poetic failure. Here the lyric speaker's definition of what poetry is traps him within a poetic crisis of his own making. The impossibility of communication calls into question whether what is occurring is in fact poetry.

\section{BUILDING THE “APPARATUS": SPENGER, LANGUAGE, AND POETRY}

Recent criticism of Victorian poetry has noticed the genre's deep involvement in contemporary accounts of physiology. ${ }^{16}$ Spencer is one of many contemporary writers who believed in a physiological poetics. Indeed, the essay that would become "The Philosophy of Language" was originally titled "The Force of Expression"-in this case, a "force" that exceeded the full control of its users. ${ }^{17}$

In Spencer's account, the most effective language is that which is closest to the things it describes. Walter Ong refers to such language as that most deeply "embedded in the human lifeworld." world" is useful here: "the sum of immediate experiences, activities, and contacts that make up the world of an individual." ${ }^{\prime 19}$ For Spencer, words connote and communicate humanity's immediate experiences of things. Indeed, the things that make up the lifeworld convey meaning better than language, when put to deictic purposes. "To say, 'Leave the room,'” Spencer writes, "is less expressive than to point to the door.... A beck of the hand is better than, 'Come here." "20 Print language is, in turn, one step further from the human lifeworld, since it is a representation of speech. Yet, in Spencer's account, print language can also resurrect the full presence of speech and of the lifeworld elements to which speech "points."

16. For physiological science's effects on Victorian literature, see William A. Cohen, Embodied: Victorian Literature and the Senses (Minneapolis: University of Minnesota Press, 2009).

17. See Russel Hirst, "Herbert Spencer's Philosophy of Style: Conserving Mental Energy," Journal of Technical Writing and Communications 34 (2004): 198-224.

18. Ong, Orality and Literacy, 43.

19. OED, s.v. "life-world," n., http://www.oed.com.

20. Herbert Spencer, "The Philosophy of Style," in Essays: Scientific, Political, and Speculative (London, 1858), 230. Further references in text. 
Any system designed to convey ideas across a wide population needs those ideas to be conveyable-which is to say, stable between minds. To this end, Spencer calls language an "apparatus of symbols for the conveyance of thought" (230). Reproducing one mind's experiences in another draws on their shared experience of the human lifeworld. Language influences its recipient by evoking the bodily memory of past experiences. Spencer notes that the "frequent cause of strength in Saxon and other primitive" languages is the "imitative character" that they present. Some words ("splash, bang, whiz, roar") are "directly imitative" of what they represent-that is, essentially onomatopoeic, whether when written down or spoken out loud (233). Onomatopoeia in general proposes that words can be formed "from a sound associated with the thing or action being named." ${ }^{21}$ The closer to the human lifeworld-to a command given successfully, or to an event experienced-the more effective a word is.

Yet language can move between reading and speech, and back again, without losing any force. This is what Spencer invokes when he describes "the act of listening to verbal articulations, or ... the silent repetition of them which goes on in reading" (254). The reader makes in her mind a virtual oral space that repeats the moment of either hearing a word said aloud or of saying it. Through print, language enters the reader's body and makes it do things, in this case resuscitate live speech. This repetition is "silent." It may not actually involve the lungs, diaphragm, and so forth. Yet as a "repetition," it evokes the prior excitement of these organs-specifically, the "mental impressions" made by their being excited (252). This account of reading as the involuntary recollection of a physiological process places the reader in a passive position. She listens and experiences this recollection but does not in any sense resist or analyze.

Linguistic efficacy depends on the reactions it creates in other organisms or on the memories of these reactions that it conjures up. For this reason, the speaking human is most linguistically efficacious at moments of high physiological excitement: "mental excitement spontaneously prompts the use of those forms of speech which have been pointed out as the most effective" (252). This "excitement" has an involuntary effect on both speaker and hearer. We generally regard highest speech as the most poised, reflective, and formally elaborate. Spencer gives a new definition to "high" speech. He suggests that excitement can produce vividness and elaborateness while bypassing reflection entirely: "The higher forms of speech acquire a secondary strength from association. Having, in actual life, habitually heard them in connection with vivid mental impressions; and having been accustomed to meet with them in the most powerful writing; they come to have in themselves a species of force" (252). Spencer makes no

21. OED, s.v. "onomatopoeia," def. la. 
mention of language's ability to frame reflection or analysis. Instead, language is always an echo of the "mental impression" created by lived experience. We might associate the word "help," overheard or in print, with the "vivid mental impression" of watching someone in distress. This recollection creates in the reader an experience similar to the physiological experience of that initial experience.

Spencer calls poetry the highest form of language: "The continuous use of these modes of expression that are alike forcible in themselves and forcible from their associations, produces the peculiarly impressive species of composition which we call poetry" (253). Spenser claims that the body cannot help but respond to excited language. Consequently, meter and language can "forcibly" control the reader/hearer's body through excitement. Poetry is a less problematic interface than prose, since poetry's "rhythmical structure" spares the reader from unpredictable forces. Spencer's account of rhythm equates the operation of body and mind through a "physical analogy" (255). "Just as the body," he writes, "in receiving a series of violent concussions, must keep the muscles ready to meet the most violent of them, as not knowing when such may come; so, the mind in receiving unarranged articulations, must keep its perceptives [sic] active" (254). Prose keeps the reader's mental guard up. Poetry, by providing a regular metrical pattern, demands less of this "economy of the reader's or hearer's attention," in turn permitting greater control over the mind (254). A "long word," highlighted by metrical stress, "allows the hearer's consciousness a long time to dwell upon the quality predicated" (253). That a word "allows" the mind to do something shows how completely language controls the reader in this account.

Spencer's theory is more instrumental than other nineteenth-century accounts of how lyric interacted with its audience. Wordsworth's "man speaking to men" leaves considerable room for a negotiation or debate that Spencer's poetry of physiological effect downplays. Like Spencer, Wordsworth does suggest that poetry creates the "spontaneous overflow of powerful feelings" in the reader, and notes the strong social "influence" of poetic language. ${ }^{22}$ Yet Wordsworth also holds to the belief that "our continued influxes of feeling are modified and directed by our thoughts." ${ }^{23}$ Wordsworthian poetic experience is, famously, "recollected in tranquility," a word suggesting bodily equipoise-something present in neither Spencer's poet nor his reader. ${ }^{24} \mathrm{~J}$. S. Mill's lyric speaker is even more interior-and so free from

22. William Wordsworth, "Preface to Lyrical Ballads," in Lyrical Ballads, with Pastoral and Other Poems, 2nd ed., 2 vols. (London, 1802), 1:xxviii, and his 1802 appendix, "By what is usually called poetic diction," 2:238, http:/ / books.google.com.

23. Wordsworth, "Preface," 1:xiv.

24. Ibid., 1:xxviii. 
the need to consider social influences-than is Wordsworth's. Mill states that "poetry is feeling confessing itself to itself in moments of solitude, and bodying itself forth in symbols which are the nearest possible representations of the feeling in the exact shape in which it exists in the poet's mind." ${ }^{25}$ The mind of the poet was to be left free of outside influences, free-as in Mill's writing more generally_to think for itself. Mill gives "feeling pouring itself out to other minds, courting their sympathy, or endeavoring to influence their belief, or move them to passion or to action" the separate term of "eloquence." ${ }^{26}$ In contrast, Spencer defines poetry as language intended to influence or move others.

\section{THE WAY OF HEARING：SPENGER AND HOPKINS'S POETIC PRACTIGE}

Isobel Armstrong argues that the speaker in Hopkins's poetry "must fuse thinking and feeling or, if possible, thought and sensation" for the reader. ${ }^{27}$ Armstrong sees Hopkins as having intended his poetry to assume control over the reader's independent thought through such "fusing." I can find no evidence that Hopkins ever read Spencer, but given the latter figure's omnipresence across the Victorian media, it would not be surprising for Hopkins to have encountered him. Yet even if Hopkins had never read Spencer's account of poetry-or, indeed, never written a poem-he would still have paralleled Spencer in his sermons and religious writings, which describe the highest forms of language as innately coercive. As we shall see, Hopkins stresses the social success of Christ's preaching, hoping to redirect that success into the English context.

Hopkins delivered his first sermon on July 6, 1879, on the occasion of the Feast of the Precious Blood. Hopkins describes Christ's blood as possessing a communicative component that attracts a hearer's attention, even if they do not know what it means. "Men bring it into their oaths," he writes, "quite senselessly. But it makes the things they talk of seem important, more worth your listening about than if they did not call them by its name. It is because they feel [Christ's blood] is important, precious, and its very name seems to communicate importance in other things." ${ }^{28}$ Those who take Christ's blood "senselessly" into casual oaths miss its true meaning. Yet, as Spencer suggests, people swear when they are excited. What Hopkins

25. John Stuart Mill, "What Is Poetry?," in Essays on Poetry, ed. F. Parvin Sharpless (Columbia: University of South Carolina Press, 1976), 12.

26. Ibid.

27. Isobel Armstrong, Language as Living Form in Nineteenth-Century Poetry (Brighton: Harvester, 1982), 15.

28. Gerard Manley Hopkins, The Sermons and Devotional Writings of Gerard Manley Hopkins, ed. Christopher Devlin (London: Oxford University Press, 1959), 13. 
adds to Spencer's account of language is his notion of God as the ultimate motivator of all "charge"-all excitement-in the world. So swearing with the word "Christ," even to those who perceive no religious connotation to the word, nevertheless has a force drawn from Christ himself.

Hopkins develops his account of language's ability to draw the hearer's attention to charge in his explication of the Paraclete, set out in a later sermon. He explains that the word's frequent translations as "helper" or "comforter" are insufficient. Hopkins expands and refines this figure by giving it a strongly aural and persuasive presence: "A Paraclete is one who comforts, who cheers, who encourages, who persuades, who exhorts, who stirs up, who urges forward, who calls on; what the spur and word of command is to a horse, what clapping of hands is to a speaker, what a trumpet is to the soldier, that a Paraclete is to the soul." ${ }^{29}$ Hopkins here makes no distinction between voluntary and involuntary exchanges of speech. If the Paraclete is truly present, "persuasion" and "command" are one and the same.

Christ himself provided the ultimate such "spur." Hopkins shows Christ overwhelming a crowd: "His mighty breath ran with roaring in their ears.... Three thousand were at one stroke convinced." 30 The physical force of Christ's speech is more important than its message. It commands rather than persuades. Hopkins emphasizes the mechanism of this conversion: the "mighty breath" expelled from Christ's lungs, its "roaring" within the "ears" of the converts, all adding up to the final "stroke" of conversion. So, the acceptance of Christ's word is an unreflective conversion to this physical sensation.

"Bidding"-gaining influence over the reader's body-is Hopkins's selfimposed poetic test. In an 1882 letter to his friend Robert Bridges, Hopkins clarifies this term, describing "finding the ear of an audience ... a nameless quality which is of the first importance ... I sometimes call it bidding. I mean the art or virtue of saying everything right to or at the hearer, interesting him, holding him in the attitude of correspondent or addressed or at least concerned."31 As "holding" suggests, Hopkins understands bidding as assuming control over the "attitude" of the reader's body. Only if the inscape has been "called out" to a reader who is held by the experience of God's presence has poetry occured.

Hopkins claims for the poet the commanding persuasion of the Paraclete. But where Christ was himself the source of the world's charge, and so did not require any additional outside charge, the observation of nature can create charge in the human poet. In this way, poet, language, and reader are all made equally charged: by the poet's observation of nature, and subse-

29. Ibid., 70 .

30. Ibid., 74-75.

31. Gerard Manley Hopkins to Thomas Bridges, quoted in Griffiths, Printed Voice, 327. 
quent expulsion of poetry. In a much-quoted journal entry from 1871, Hopkins describes "inscape," a concept that draws on his understanding of God's presence in all physical things: "I thought how sadly beauty of inscape was unknown and buried away from simple people and yet how near at hand it was if they had eyes to see it and it could be called out everywhere again." 32 I use Armstrong's definition of the term: inscape is "the unique, individuating particularity of the object which creates not only its identity but its unity"-its quiddity, in other words. "Instress" is "the specific energy with which [a] being is charged and which renders a particular emotion to the perceiver." ${ }^{\prime 3}$ Instress and inscape cannot be separated. The essence of a thing is also what part of that essence it communicates to others; communicating a state and existing in that state are the same.

Another component of Hopkins's core physics is the assertion that the human lifeworld is also God's language. There is no distinction between a verbal description of a tree, the tree itself, and the force of God's presence in the tree. Hopkins saw poetry as "call[ing] out" the essences of things to others, making the reader aware of God's presence-that-is-language-that-isthe-thing-described. Spencer's and Hopkins's definitions of poetry are in this regard closely aligned. Both suggest that words can call out physiological experiences. For Spencer, memory is the catalyst. For Hopkins, in contrast, the catalyst is always the momentary experience of God's charge. His poetry does not remember experience. Instead, in describing the natural world or human events, it aims to create a new experience of equal force in the reader.

Hopkins's account of a mind noticing the intricate details of the world (inscape) is incomplete without some mechanism to convey (instress) those details to others. There is no privacy or idiosyncracy in Hopkins's charged minds. The poet experiences the details of the world and stores them in poetic language. What defines this language as poetry is that it can reconstitute the full force of the poet's original experience in the reader or hearer.

The inscape journal entry presents a master trope that harkens back to Hopkins's description of Christ's "roar" of speech and runs throughout Hopkins's poetry. This trope describes the speaker's emotions when experiencing the charge present in a natural or human setting. This charge wells up and finally bursts out. The most pronounced example of this is the

32. Gerard Manley Hopkins, The Journals and Papers of Gerard Manley Hopkins, ed. Humphrey House and Graham Storey (Oxford University Press, 1959), 221.

33. Armstrong, Language as Living Form, 14. Inscape and instress have been so thoroughly treated in Hopkins criticism that I do not attempt a systematic discussion of them here. Inscape's oral nature is critically well established. James Wimsatt, for example, discusses "the notion of the inscapes of spoken language" in Hopkins's Poetics of Speech Sound: Sprung Rhythm, Lettering, Inscape (University of Toronto Press, 2006), 13. 
phrase "Enough! The Resurrection," which marks the central logical turn in "That Nature is a Heraclitean Fire" (1888): away from the possibility of nature as a purposeless "bonfire," and toward what the poem's subtitle calls "the comfort of the resurrection" and the possibility of a redeeming God. ${ }^{34}$

Spencer describes poetry's effect on the body measures as a series shocks or concussions. In "The Wreck of the Deutschland," Hopkins designed a poetic structure that comes closer to Spencer's poetry of bodily shocks than does regular English meter. Sprung rhythm, which is organized around a number of stressed syllables per line rather than the general foot-based English meter, allows for as many unstressed syllables as the poet needs. This meter makes "concussions" (to use Spencer's term) rather than feet, the central organizing principle of poetry. Longer words can receive greater emphasis, and shorter ones greater intensity, through the manipulation of shocks. Further emphasizing his control over his readers, Hopkins attaches an "Author's Note" to the "Deutschland." This note suggests that a didactic supplement is required in order to appreciate what the poem is. This statement introduces us to the word "tell," which will recur throughout the poem. The Deutschland does not debate or engage but simply "tells": communicates ineluctably once the channel of reception is opened. The Deutschland disaster was itself telling: that is, it was an event about which it was difficult to have a wide variety of reactions. On December 6,1875 , the Deutschland, a passenger ship en route to New York capsized in the midst of a North Sea gale. On board were five Franciscan nuns, exiled from Prussia. Hopkins stated that the event "made a deep impression on me, more than any other wreck or accident I ever read of." He was not the only one: as Norman Weyand writes, "Hopkins, together with all England, was evidently moved."35

This story charged the poet to write the poem. It did so because he could expect the charge to reach others. Catholics did not find themselves "together with all England" all that frequently. The Deutschland wreck provided a moment when a topic sympathetic to Catholicism had appeared prominently within the national conversation. The description of dying passengers crying out for rescue in the face of natural forces exemplifies how the stresses created by the natural world could produce speech-and, furthermore, how this speech could retain its original force even after having passed into print. The Times's account of the wreck mentions the tallest of the nuns crying out "'Oh Christ, come quickly' till the end came." ${ }^{36}$ Walter Ong writes that Hopkins regarded the report with a "degree of imminence,

34. We see other similar examples throughout Hopkins's poetry: "The Windhover" (1877) is dotted with exclamations, and "Spring and Fall" (1880) turns from questioning to providing answers with an "Ah!"

35. Norman Weyand, quoted in Griffiths, Printed Voice, 345.

36. "The Loss of the Deutschland," Times (London), December 11, $1875,7$. 
associated with speech."37 The nun's cries were encoded by the newspaper and then sprang out with full force to Hopkins. The "Deutschland" poem aims to further transmit this force to the reader. The nun has witnessed the divine charge present behind the wreck. This charge has cathected her and led her to speak. Her charged speech enters the newspaper report itself. The speaker, reading the report is charged, and therefore writes the poem. His writing again encodes his charge and releases it in the reader.

The speaker serves as a paraclete, "calling out" God's presence even in the wreck. First, though, the speaker describes how he came to be a paraclete. The second and third stanzas of the poem about the Deutschland detail the conversion process that first brought the speaker to the state of excitement that causes the exclamation ("Thou mastering me / God!") that begins the poem. The precise nature of these events is a crux in Hopkins scholarship. I suggest that the reason for the lack of detail regarding this event is to make the process of inspiration clearer. Indeed, the speaker shows his role in the process as verbal but almost involuntary:

I did say yes

$\mathrm{O}$ at lightning and lashed rod;

Thou heardst me truer than tongue confess

Thy terror, O Christ, O God;

Thou knowest the walls, altar and hour and night:

The swoon of a heart that the sweep and the hurl of thee trod

Hard down with a horror of height:

And the midriff astrain with leaning of, laced with fire of stress.

These lines alternate between two tenses. The condition of the narrator's awareness begins in the past tense but remains steady in the present continuous. What began with the narrator's conversion is still happening in the present. This alternation shows that past-tense events can be fully reconstituted in the present, a central belief in both Hopkins and Spencer's poetic systems. The second stanza constructs the speaker as paraclete through his awareness of God's charge within the world. This allows him to speak as a poet. "I did say yes," he announces, presenting two interlinked meanings: "I, in fact, said yes at a point in the past," and "I said yes, as I was required to do." The favorite Hopkinsian speech act of exclamation inflects this second meaning. The speaker confirms that he, in fact, acted as he would be expected to as a Spencerian lyricist, crying out in reaction to the excitement of God's "lightning and lashed rod," the force of this divine presence in the physical world. The narrator spoke because he had to; infused with God's charge, how could he not?

37. Walter J. Ong, Hopkins, the Self and God (University of Toronto Press, 1986), 211. 
When the narrator announces, "Thou heardst me, truer than tongue, confess," he addresses two entities: God, and the reader. The second-person address here works analogously to an electrical circuit. The speaker announces that, charged by God, he will in turn charge the reader. Describing his initial conversion, the speaker notes that his speech was powerful by association ("truer than tongue") but also powerful as speech in itself. Spencer's subordination of speech to things, along with his simultaneous belief that speech can fully reinvoke the presence of things, clarifies the paradox at the heart of this statement, which we might paraphrase as "you heard me say something truer than hearing." "Heardst"-hearing-captures the speaker's simultaneously exclaimed and internalized confession. Physical hearing is compatible with the truer-than-hearing, because Christ suffuses the air through which sound travels and hearing operates. Further, that belief in writing's ability to convey a charge, shared by Spencer and Hopkins alike, means that if the poem is operating as it should, this charge has also been conveyed to the reader. If the poem works on its own terms, it has connected the reader to God, with the speaker's language serving as the intermediary.

The narrator next emphasizes the bodily mechanics of the conversion ("The swoon of a heart") in a way that deemphasizes this process's particularity to him (13). He becomes "a heart" (13). This is to say, an undifferentiated human creature-indeed, metonymically simply an organ-experiencing the charged terror that confirms God's presence. The reader, too, could be such a heart: overwhelmed by a physical reaction to God's language but also as a result charged with the grandeur of God. And charged bodies do not simply inhale. They also expel breath and speech. One of the key materials in this poem is the air in the vibrations of which poetic language-as well as God's analogous language - makes itself manifest. In this second stanza, air is breath moving through the body to produce speech. Later, it will appear as a natural force buffeting the wreck. The narrator equates these two versions of air movement. Air produces poetry as a force of nature pushing on bodies, exciting them to speak. It also produces poetry as air pushed out of bodies, producing the speech that Hopkins and Spencer agree is the basis of poetic language itself. It finally produces poetry as the intermediary element through which sound passes, permitting "hearing," and so the excitement of the reader, to occur. Following the motion of breath through the human body, in this stanza the narrative moves from the heart to "the midriff" - the diaphragm- "astrain" (16). The speaker may be an individual heart, but the phrase "the midriff" suggests that the breath that flows through him is part of something larger. In one sense, "midriff" refers to the literal diaphragm of the speaker. This diaphragm is inspired to speak by the speaker's awareness of God's presence. What the speaker says is encoded as writing. Via the text, the reader receives the full force of the speak- 
er's original utterance. So, the speaker's midriff, astrain, becomes “a strain," a sequence of musical notes. ${ }^{38}$

God's language charges those who become aware of it. It produces a strong physical reaction. In the face of the shock of God's charge, which is simultaneously the language exclaimed by the world, the narrator writes that

I whirled out wings that spell

And fled with a fling of the heart to the heart of the Host.

My heart, but you were dovewinged, I can tell,

Carrier-witted, I am bold to boast,

To flash from the flame to the flame then, tower from the grace to the grace.

$(20-24)$

The "wings" that enact this translation "spell"- that is, the speaker's conversion is itself a message that might speak to others. A "fling" of the "heart" moves the speaker into full communion with the "Host." That "fling" is both an unguided throwing of his essence and also a muscular contraction that pushes out air as speech, bringing him into what is for the poem complete communion. This total awareness of God requires the speaker to exclaim his awareness ("I did say yes"). So the Host is itself a "heart" that "in-spires" (breathes air but also spirit into) the poet. Inspiration gives the poet breath but also that interior height of awareness (an in-spire) that produces poetry. A great communion with the host-in-air is also required to speak that long last line, which requires a great intake of breath in order to be read aloud. ${ }^{39}$

Like the breath of Christ commanding his followers through their ears, the narrator describes his conversion as an involuntary physical act. The narrator again addresses his "heart," calling it "dovewinged, I can tell" (28). The biblical connotations of "dove" are obvious. However, pigeons-the more common name of the Rock Dove-also carry messages. The speaker's heart was "dovewinged," in two senses. First, it knew where to go, to God, when "flung" by the disorientation of conversion. Second, it was itself a message-carrying device. The speaker can speak as a poet-can "tell" the reader-because his converted heart became "dovewinged" and "Carrierwitted." The speaker could discern God because his "dovewinged" heart, like a dovewinged bird, intuited its proper destination. In making this journey, his heart becomes a message itself-specifically, that others, charged, can find God.

The narrator's charged exclamation can travel through print media. One means of long-distance communication, carrier birds, was deployed

38. OED, s.v. "strain," n. 2, def. 13a.

39. Chalcedony Wilding suggested this to me. 
one line earlier. So, the word "tower" in the narrator's description of his conversion ("tower from the grace to the grace" [30]) may be said to refer to telegraphy, a powerful media force in 1875 . The speaker can now communicate "the grace" over a long distance, from the grace he himself has found to the grace his poetry will call out in others. By bringing newspapers and telegraph within the quotidian physics of poetry, the poem announces that it will speak through contemporary media technologies. The message of a heart inspired through the media prepares us for the poem's second half. Here, the inspired heart will narrate the wreck of the ship in a way that will inspire others. The central figure of the poem's first half is its speaker. In its second half, this speaker narrates as he is charged by the language of the so-called Tall Nun, one of the shipboard passengers mentioned in the Times report.

First, however, the speaker narrates the events of the wreck as they appear to those on the ship who are unaware of God's charge. "The infinite air" of the storm is "unkind" to these characters: not simply lacking in care but also not kind-not linked-to them (100). Absent a perspective aware of God's presence, the wreck is simply meaningless and brutal:

One stirred from the rigging to save

The wild woman-kind below,

With a rope's end round the man, handy and brave-

He was pitched to his death at a blow,

For all his dreadnought breast and braids of thew:

They could tell him for hours, dandled the to and fro

Through the cobbled foam-fleece, what could he do

With the burl of the fountains of air, buck and the flood of the wave?

(121-28)

The sailor's attempts to "save" his "kind" fail. Conventional heroism, his "dreadnought breast and braids of thew," produces no heroic end. The "woman" is less human "kind" than "wild"—animal—flesh. When a seaman becomes fatally stuck in the rigging in an unsuccessful attempt to save someone, the passengers "could tell him for hours," yet what they see is simply his body (126). As in the author's note, "tell" evokes only ineluctable communication. You cannot tell a dead body anything. Yet you can certainly make it out as it swings about trapped in rope. Indeed, the spectacle would be hard to turn away from. What this uncharged view of the storm presents to us, then, is "the heartbreak hearing a heartbroke rabble" $(128,133)$. Literal and figurative hearts break in the face of the storm. "Heartbreak" is an odd grammatical subject. It is odder still that heartbreak is said to "hear." Yet this arrangement is consistent with the poem's first part. The "heartbreak" is, in this case, nature, causing the wreck. Nature is the only thing that "hears" the "heartbroke rabble," those on deck now reduced to a word 
that suggests their mere humanity. These are "broken" physically, but also "broken"-incomplete, defective-in their inability to experience God's language, God's presence, in the storm.

To a perspective aware of God's presence guiding it, the shipwreck is also beautiful, with its "fountains" of air and foam that is like "fleece." To see it in this way, though, we must accede to the narrator's point of view. The poem's metrics analogously restrict the reader's choices. We cannot help but note the accent marks that dot these paragraphs. These accents are visually analogous to the snow that buffets the passengers. The "Wiry and whitefiery and whirlwind-swivellèd snow" buffet us to read against our natural metrical inclinations, just as the poem's language tells us to see "fleece" in the fatal blow of a wave (103-4). The speaker will not, in other words, leave the reader unguided in the way that those on the ship are. He can serve as guide, he finally reveals, because of his inspiration by the words of the Tall Nun.

The speaker describes the nun in language that continues the respiratory conceit from the poem's first section. She arises "breasting the bábble," taking the air into her heart, her breast-as the narrator does in the opening stanzas-as charge and expelling it as inspired speech (135). "Tell" appears again. Here it shows a speaker charged by God's presence and made by it to speak: "A prophetess tówered in the tumult, a vírginal tóngue tóld" (136). The nun "towers" because she is the tallest of the five. But "towers" also connotes telegraphy and, with it, the notion of reaching others across a wide distance. In stanza 18, the narrator writes that the nun makes "words break from me here all alone" (139). Her charge produces an exclamation in him, even though she is hundreds of miles, and several days, distant from him. It makes no difference that he is "Away in the loveable west / On a pastoral forehead of Wales" while the event is taking place (185-86). The newspaper report connects them. The nun's "cry" produces a response in him that is every bit as intense as if he were there on the wreck. The narrator calls the nun "my heart" in part because she is part of the same bodily system as he is. God breathes air into them, and they exclaim God's presence.

That the narrator, the nun, the world, language, and God are all conflated produces some of the most complex language in the poem: "here was heart-throe, birth of a brain, / Wórd, that heard and képt thee and úttered thee outríght" (239-40). "Throe" is particularly polyvalent. The "heart-throw" references the "fling" of the speaker's heart from the poem's third stanza, which inaugurated his ability to speak as a poet. The "heartthroe" also refers to the nun on board the ship, as the physical shock of air and water collide with the body and the physical force of that voice expelling inspired speech. For both narrator and nun, a brain-their mindsare made by a brain — results from a shock. God is a "Wórd," in many senses. He is the divine Logos but also the word that the nun utters. He is also the 
meaning that the narrator intends. He is, finally, a stress that-through the emphasis mark on "Wórd" - the reader must acknowledge in order to read the poem correctly (240). This stress, and others like it, demonstrate where Hopkins falls within the account of the "mediation" of the poetic voice into "multiple voices" that Prins proposes. Because the "Deutschland" asserts that poetry can convey a precise experience to the reader, the poem presents a poetic surface that-through its stress marks-limits the possibility of "multiple voicings."

As the language of "breaking" shows, the speaker's reactions are involuntary. God exerts force on him, through the nun's language, as much as God does on the nun herself. The speaker continues to feel the wreck's effects on him as they drive him to continue the poem. These past-tense events are given a present charge by a cluster of exclamations, which roll across line breaks as the waves run over the deck of the foundering ship: "Ah, touched in your bower of bone / Are you! turned for an exquisite smart / Have you!" (137-38). The last of these exclamations is the most closely tied to the creation of poetry: "make words break from me here all alone, / Do you!" (139-40). Repeating "break" from the earlier stanzas, the narrator describes poetry making as every bit as involuntary as the action of a ship in a wreck. The narrator makes the comparison between himself and the shipwreck explicit, calling God the "ocean of a motionable mind"- that is, the surroundings buffeting the poem's speaking intelligence, causing him to write the poem (253).

At the poem's conclusion, the speaker calls for the reconversion of England to Catholicism. Reading the "Deutschland" in light of Spencer and Hopkins's shared theorizing of poetry's public influence explains this remarkable fantasy. The poem calls, in effect, for what it declares a poem to be. This will be "A released shówer," a grand releasing of energy that would make the populace aware of God's charge. The speaker calls for this energy to be "flásh[ed] to the shíre," as lightning strikes the ground or as a telegraph flashes its message to a rural recipient (273). Despite the unlikeliness of what it calls for, the conclusion of "Deutschland" follows naturally from its beliefs about the effect of poems on persons. If it does what Hopkins's poetic theory suggests poetry can do, the poem should charge its audience.

The workings of charge explain the strong antireflective element in the poem's last line, which calls for God's "reign" to "roll" through "Our héarts' charity's héarth's fíre, our thóughts' chivalry's thróng's Lórd” (280). "Reign” and "roll" both present the notion of involuntary control, seconded by the stress markings that demand a particular enunciative force. This line requests a mass emptying of the private elements of the nation's minds. It links the nation's selves ("Our héarts" and "our thóughts") to a charged "fire" and a heavenly "Lórd," each of which will dissolve the boundaries of the individual and of individual "thought." Selves will stand not on their own but as 
part of a "throng." This "throng" is suggested by the line's dense weave of possessives. This intermingled syntax describes the whole of a converted nation in the way that, presumably, it would seem to God. In the world that Hopkins calls for, the human "heart" possesses no reserve, no privacy, from the divine "fire." The privacy of "thought" is herded into a public "throng," charged with awareness of the "Lórd" that, stressed both theologically and graphematically, concludes the poem.

\section{II . CONCLUSION: THE PERSISTENGE OF PUBLIC INFLUENGE IN LATE HOPKINS}

It is difficult to imagine a poetics more brutally inhospitable to the actual conditions that would attend Hopkins's poetic career than the one I have described. The "Deutschland" was not published until after the poet's death. The inhospitable conditions are reflected in Hopkins's late poetry. The speakers of these poems still feel something like the charge of the world themselves. But, if this charge cannot be passed along, it cannot fulfill Hopkins's definition of poetry, since no transmission of charge-no excitement of the reader-is present.

Hopkins's late poetry revises the master trope of exclamation that appears throughout his work. His later speakers are also often made to exhale sound by their attachment to the world. However, these sounds may not be heard or interpreted by others-and so by the terms set out by Hopkins himself, may not be poetry. "No Worst, there is none" (1885) shows a narrator whose body remains ineluctably attuned to the language of the world. Here, though, the connection brought about by charge goes awry. The force of the narrator's attention produces only pain: "Pitched past pitch of grief, / More pangs will, schooled at forepangs, wilder wring" (1-2). The speaker remains connected to the world, made to feel "pangs" by his awareness of its energy. Here, however, he cannot communicate them to others. The speaker's connection to the world now torments him. He is "pitched"- made to express sound outwardly, at a particular frequency — past a "pitch of grief," a sound that might be recognized as such to other humans. The narrator cannot detach himself from reading the world's frequency, a third meaning for "pitch." So finely attuned is his body, in fact, that even the absence of pain is "schooled" to be the expectation of future pain. His body is again forced to speak. Yet now his "cries heave, herds-long" (5). That his "cries heave" retains the physical, expressive, compulsive force of expression that appears in the "Deutschland": speech making is again involuntarily. Yet these words may simply be noises, as bereft of human inspiration or message as the movement of a "herd" of animals. Like the members of the "Deutschland's throng," he cannot (as the member of a "herd") stand reflectively outside of his experience. 
What he finds in these experiences is only pain. "Comforter," the narrator asks, echoing the paraclete sermon, "where, where is your comforting? / Mary, mother of us, where is your relief?" (3-4). Through God's perspective, the "Deutschland" narrator was able to see beauty in the shipwreck. This narrator seems unable to find such a perspective. And as divine inspiration is lost, so too is the final knowability of language and the human mind: "the mind, mind has mountains; cliffs of fall / Frightful, sheer, no-man-fathomed" (910). The narrator here seems terrified of an interior unconscious, and an exterior landscape, in which God's language may not be read.

For much of its first line, "Spelt from Sibyl's Leaves" (1886) suggests a return to the readings of charged nature that marks Hopkins's earlier work:

Earnest, earthless, equal, attuneable, | vaulty, voluminous, ... stupendous

Evening strains to be tíme's vást, | womb-of-all, home-of-all, hearse-of-all night.

The stated subject of these adjectives is "evening." Their unstated subject is the possibility of transcending merely earthly existence. The movement of natural time that evening marks can at once be straightforward ("earnest") and also transcend mere physical existence and be "earthless." The poem continues to suggest that some ordering principle may be discernable in nature. Evening might even be "attuneable"-shaped, somehow, to a correct pitch.

This first line suggests an optimism that its ellipsis lets hang before the poem crushes it. For evening is also "stupendous." It is tremendous but also stupefying - preventing, rather than encouraging, speech. The second line repeats this indecisive process. Again, the poem considers the idea that evening, and so nature, might have within them some ordering principle compatible with human understanding but concludes instead that evening "strains," an insufficient container or meaning maker in human terms, a "womb-of-all, home-of-all, hearse-of-all." Ultimately, the possibility of an order in nature collapses: "For eárth | her being has unbóund; her dápple is at énd, as- / Tray or aswarm" (6-7). "Dapple," a word associated in Hopkins's poetry with inscape-and so particularity (see "Pied Beauty") —is "at énd," because the world finally unbinds-tears apart- "her" own self. So "dápple," inscape, the essence of things, is finally "as- / Tray or aswarm." That is, it is either subject to the animal, nonhuman ordering of a "swarm," or, alternately, it is as "as- / Tray," as disordered or lost, as the word "astray" itself, divided as this word is across two lines. Even as it yanks the reader jarringly across the line break, the poem suggests that it may be leading her nowhere-or, at least, not toward the sort of ordering principle that it first suggested.

The world may simply be a wreck unredeemed by an ordering God. "Sibyl's Leaves" includes a wreck homophone: "a rack," in this case an apoc- 
alyptic vision of a self completely tortured (as on a "rack") within itself. For this narrator, hell is total privacy, accompanied by the failure of that mode of interpersonal connection that manifestation promises. In this rack, "selfwrung, selfstrung, sheathe- and shelterless, thoughts agaínst thoughts ín groans grind" (14). Here, the possibility that oral communication might convey a charge between people has collapsed; "hearing" and its attendant "heart"-making are not present. Instead, the narrator's "thoughts" are "selfwrung," communicating with no one. With the collapse of communication comes the collapse of Hopkins's entire poetics. Instress confirms inscape. The ability to communicate a thing's essence verifies God's presence within that thing. Now, when things are expressed, they "groan" against one another. What they communicate may have no purpose. This narrator's perspective may be like that of those standing on the Deutschland wreck, unable as they are to connect with charged language. There is no mediating figure, no nun or other suitable poetic speaker, to make such a connection. If the narrator cannot make a connection to God's linguistic charge, he expends himself on himself fruitlesslessly, unable to find that public influence that is the test of whether poetry is present.

When these groans were finally heard-when Hopkins was revived by the Modernists as a sort of Victorian precursor to their own poetics-these subsequent interpreters appreciated the written texture of his poetry while neglecting the oral charge that this poetry was meant to convey. The Modernists do not doubt Hopkins's poetic gift, and Practical Criticism's emphasis on poems as systems unto themselves-rather than as contributions to a national conversation-revealed gorgeous new depths in the language of Hopkins's poetry. ${ }^{40}$ Yet it did so at the expense of describing that interpersonal poetic connection that Hopkins's poetry so intricately describeseven when, as in the late sonnets, this connection is not present or working. Considering Spencer's "Philosophy of Language," and that wider culture of Victorian orality for which it speaks, brings back into focus the emphasis on wordly effect that runs throughout Hopkins's poetry.

In this, Hopkins may even be read as a case study for Victorian poetry more generally. Considering eighteenth-century verse in light of its distance from contemporary poetry, an anonymous writer for Temple Bar describes that century's poetry as an incomplete movement. From the vantage point of 1861, the author notes that "a great change was then working from within. It was the hidden spirit of man, long yearning for a vent, that struggled for manifestation." 41 "Manifestation," the bringing of an interior "spirit" out in to the world, separates the poetry of the eighteenth century from that of the

40. A classic collection of New Critical writings on Hopkins is F. R. Leavis et al., Gerard Manley Hopkins: A Critical Symposium (Norfolk, CT: New Directions Books, 1945).

41. "Thomas Gray and the Literature of the Eighteenth Century," Temple Bar 3 (1861): 418. 
late nineteenth-for this writer as for Spencer and Hopkins. One strain of Victorian poetry and poetic theory believed that poetry should grant wide social influence to a poet's mind. Taking Spencer and Hopkins together shows us that this influence could be imagined not only as an opportunity but also as a burden. Hopkins's tortured commitment to poetic publicityeven in its apparent absence-points the way toward work on the sense of obligation to public impact of other Victorian poets. 